\title{
Nutrient Content, Phytonutrient Composition, Alpha Amylase, Alpha Glucosidase Inhibition Activity and Antioxidant Activity of the Stoechospermum Marginatum Collected in Pre Monsoon Season
}

\author{
Reka Palanivel $^{1^{*}}$, Thahira Banu Azeez ${ }^{1}$, Seethalakshmi Muthaya ${ }^{2}$ \\ ${ }^{I}$ Deportment of Home Science, Gandhigram Rural Institute Deemed University, Gandhigram, Dindigul District, Tamil Nadu, India \\ ${ }^{2}$ Faculty of Agriculture and Animal Husbandry, Gandhigram Rural Institute Deemed University, Gandhigram, Dindigul District, Tamil Nadu, India.
}

\begin{tabular}{l}
\hline A R T I C L E I N F O \\
Research Article \\
Received 30 August 2016 \\
Accepted 24 February 2017 \\
\hline
\end{tabular}

Keywords:

Stoechospermum marginatum

Phytonutrient

Aqueous

Antioxidant activity

Therapeutic value

${ }^{*}$ Corresponding Author:

E-mail: reka.vijivelu@gmail.com

\begin{abstract}
A B S T R A C T
The objective of this study was to investigate the nutrient content, phytonutrient composition, physicochemical properties, alpha amylase and alpha glucosidase inhibition activity and antioxidant activity of the brown algae Stoechospermum marginatum collected from Gulf of Mannar, Tamil Nadu, India in pre monsoon season (JuneSeptember, 2015). Six and eight hours of ethanol and aqueous extract of Stoechospermum marginatum were used for phytonutrient screening, alpha amylase, alpha glucosidase inhibition activity and antioxidant activity. From the results of the study it is understood that Stoechospermum marginatum contain a high amount of carbohydrate, protein, crude fiber and phytonutrients like tannin, flavonoid, saponin, alkaloid, terpenoids, steroid and total phenolic content. The physicochemical properties namely Water absorption and Swelling power were very promising. Alpha amylase and alpha glucosidase inhibition activity was recorded to be high in both aqueous and ethanol extracts of eight hour extraction than in extracts taken from six hours extraction. Antioxidant activity was detected using DPPH, FRAP, beta carotene scavenging and $\mathrm{H}_{2} \mathrm{O}_{2}$ assay and found to have a high radical scavenging activity. Stoechospermum marginatum possess a valuable amount of total phenolic content and other phytonutrients and physicochemical properties, it may the reason for the potential inhibition of alpha amylase, alpha glucosidase and antioxidant activity. It is concluded from the study that the brown algae may be incorporated into foods to enhance their nutritional and therapeutic value.
\end{abstract}

\section{Introduction}

Seaweeds or marine macro algae are plants and economically, commercially valuable living marine resources that belongs to the primitive groups of non flowering plants (Paul, 2013). Seaweeds are commonly categorized into three groups such as Chlorophyceae (green seaweed) Phaephyceae (brown seaweeds), Rodophyceae (red seaweeds) especially on the basis of the pigments and the stored food materials (Jagadeesan et al., 2010). Seaweeds are reported to be rich in soluble dietary fibers, protein, minerals, vitamins, fatty acids with a low calorific value (Mohamed et al., 2012). In coastal belts of India 434 species of red seaweeds, 194 species of brown seaweeds and 216 species of green seaweeds are available (Krishnan and Narayana Kumar, 2010).

Brown seaweed (Phaephyceae) is the largest and most complex type of algae having brown, olive or yellowish brown in colour. They are about 1800 species of brown seaweeds broadly distributed from tropical to polar zones of ocean in the world (Indrawati et al., 2015). Brown seaweeds are known to contain most of the bioactive compounds than red and green seaweeds (Seafood plus, 2008). Red and brown algae are mainly used as human food sources (El-Said and El-Sikaily, 2013). Brown algae have a variety of biological compound including pigments, fucoidans, phycocolloids and phlorotannins (Rajamani et al., 2010). Number of research studies have reported that the chemical composition of the macro algae vary depending on, geographical distribution, habitats, maturity, seasons and the principal environmental conditions, such as water, temperature, salinity, light, and nutrients (Kaimoussi et al., 2004; Ortiz et al., 2006; Mesyasz and Rybak, 2010). Stoechospermum Sp. (Phaephyta, Dictyotales) is a brown alga having greenish brown thalli that is erect, tufted and linear $7-26 \mathrm{~cm}$ height. It is attached to rhizoids and is present as drift materials in sandy beaches (Abbas and Shameel, 2010). With thus background the study was undertaken to analyse the nutrient content, phytonutrient composition, alpha amylase and alpha glucosidase inhibition activity, antioxidant activity and physicochemical properties of the Brown algae Stoechospermum marginatum collected from Gulf of Mannar, in pre monsoon season (June to September). 


\section{Materials and Methods}

\section{Collection of Samples}

The selected edible brown seaweed Stoechospermum marginatum was collected from Gulf of Mannar the South Coast area of Rameswaram, Tamil Nadu, India in the month of June to September, 2015 (Pre monsoon season). The collected seaweed was washed and dried. The dried sample was powdered and stored in High Density Poly Ethylene packs (HDPE).

\section{Sample Preparation}

The powdered sample was used for the determination of nutrient content, phytonutrient quantification, alpha amylase and alpha glucosidase inhibition activity, physicochemical properties and used for solvent extraction with ethanol and aqueous $(1: 10)$ at $37^{\circ} \mathrm{C}$ temperature for six and eight hours. The final extract was obtained and filtered by Whatman No.1 filter paper and the filtrate was stored in refrigerated condition, which was used for the phytonutrient screening and alpha amylase and alpha glucosidase inhibition activity. Seaweeds contain a high amount of polysaccharides in the form of hydrocolloid and it has a coarse structure hence for extraction of phytonutrients the temperature and time has been modified from the standard extraction procedure. Thus the extraction was carried out at two different timings of six and eight hours.

\section{Determination of Nutrient Content}

The powdered sample was used for the determination of nutrient content using standard procedures namely carbohydrate (Dubois, 1956), protein (Lowry, 1951), fat (Socsplus SES04R), crude fiber (Maynard, 1970), beta carotene (Ranganna, 1976), vitamin C (Harris and Ray, 1935), moisture (AOAC, 1990) and ash (AOAC, 1990).

\section{Determination of Phytonutrient Composition}

The six and eight hours of ethanol and aqueous extracts of $S$. marginatum was subjected to preliminary screening of different phytonutrients such as tannin, flavonoid, saponin, anthroquinone, alkaloid, terpenoids, cardiac glycosides, steroids, glycosides using standard procedures described by the Harbone (1973). Further the phytonutrients tannin (Schanderl, 1970), flavonoid (Bohm and Kocipai Abyazan 1994), saponin (Obdoni and Ochuko, 2001), alkaloid (Harbone, 1973), terpenoids (Ferguson, 1956), steroids (Mann et al., 2010) and total phenolic content (Malik and Singh, 1980) were quantified.

\section{Determination of Alpha Amylase and Alpha} Glucosidase Inhibitory Activity

The six and eight hours of ethanol and aqueous extracts of Stoechospermum marginatum were determined for the inhibition activity of alpha amylase (Miller, 1959) and alpha glycosidase (Krishnaveni et al., 1984).

\section{Antioxidant Activity of the Stoechospermum Marginatum}

The ethanol and aqueous extracts of Stoechospermum marginatum were investigated for the antioxidant activity using different assays such as DPPH (2, 2- diphenyl -1picrylhydrasyl) (Wang et al. 1998), Ferric Reducing Antioxidant Power (FRAP) (Benzie and Strain 1999), $\mathrm{H}_{2} \mathrm{O}_{2}$ radical scavenging assay (Ruch et al., 1989) and Beta carotene bleaching assay (Velioglu et al 1998).

\section{Physicochemical Properties of Selected Edible}

Seaweed

The selected edible seaweed was determined for the physicochemical properties such as Bulk Density (BD) (Narayana and Rao, 1984), Water Absorption Capacity (WAC) (Beuchat 1977), Oil Absorption Capacity (OAC) (Beuchat, 1977) and Swelling Power (SP) (Leach et al., 1959).

\section{Statistical Analysis}

The nutrient content, phytonutrient composition, alpha amylase and alpha glucosidase inhibitory activity and physicochemical properties were performed in triplicate and mean, standard deviation were calculated.

\section{Results and Discussion}

The brown algae Stoechospermum marginatum was collected from Gulf of Mannar in pre monsoon season (June - September, 2015) and evaluated its nutrient content, phytonutrient composition and alpha amylase and alpha glucosidase inhibition activity, antioxidant activity and physicochemical properties, the results are discussed below.

Nutrient Content of the Stoechospermum Marginatum

The nutrient content of Stoechospermum marginatum is presented in Table1. Stoechospermum marginatum contains $40.05 \pm 0.8, \quad 20.4 \pm 0.75, \quad 4.5 \pm 0.4, \quad 14.1 \pm 0.15$, $7.63 \pm 0.25$ and $13.8 \pm 0.15 \mathrm{gm}$ of carbohydrate, protein, fat, crude fiber, moisture and ash respectively. Peng et al. (2013) reported that 45.73 percent of carbohydrate is present in brown seaweed Sargassum nazhouense. Similar results were reported by Banerjee et al. (2009) the highest amount of carbohydrate was detected in the pre monsoon season. The carbohydrate values are correlated between the salinity and surface water temperature. Murugaiyan et al. (2012) reported that Stoechospermum marginatum contain $15.8 \pm 0.8, \quad 14.88 \pm 0.84$ and $3.58 \pm 0.45 \mathrm{~g}$ of carbohydrate, protein and fat respectively. Ahmed et al. (2015) reported that 11.43 and $4.23 \mathrm{~g}$ of protein and lipid respectively in Stoechospermum marginatum. In the present study the protein content of the seaweed was higher than the other reported research studies carried out for the same seaweeds. However the fat content of the seaweed was found to correlate with the values already reported. Fleurence (1999) reported that the protein content of seaweeds varied not only between species but also between seasons. Roslin (2003) reported that among the seaweeds analysed the maximum protein content by $S$. 
ilicifolium $(28.2 \%)$ and S. wighttii (28.2). Vitamin C and beta carotene content of the Stoechospermum marginatum was $10.6 \pm 4.6 \mathrm{mg}$ and $2.33 \pm 0.4 \mathrm{mg}$ respectively.

\section{Phytonutrient Composition of the Stoechospermum Marginatum}

The tannin, flavonoid, saponin, alkaloids, terpenoids, cardiac glycosides were present in both extracts taken at six and eight hours with ethanol and aqueous. Anthroquinone, steroids and glycosides were only present in the ethanol extract and found to be absent in aqueous extract. From the results of Phytonutrient composition Table 2 it is clear that $12.6 \pm 0.41,6.5 \pm 0.30,25.9 \pm 1.8$, $7.3 \pm 0.49,5.4 \pm 0.09$ and $47.3 \pm 1.15$ percent of tannin, flavonoid, saponin, alkaloid, terpenoids and steroids respectively. Kumbhar, et al., (2014) evaluated the alkaloid content of brown algae and reported that the Sargassum cinereum, S. ilicifolium, S. tenerrimum, and Padina tetrastomatica had 5.50 $\pm 0.035,5.44 \pm 0.028$, $5.64 \pm 0.035$ and $5.58 \pm 0.055 \mathrm{mg}$ respectively are present in the selected seaweed. Total phenolic content of the Stoechospermum marginatum was found to be in $141 \pm 1$ and $86.8 \pm 0.74 \mathrm{mg} \mathrm{GAE} / \mathrm{g}$ in ethanol and aqueous extracts respectively. Foon et al., (2013) reported that the phenolic content of Eucheuma cottonii (red seaweed) and Padina $s p$ (brown seaweed) had $8.71 \pm 0.009$ and $14.58 \pm 0.12 \mathrm{mg}$ respectively. Parthiban et al., 2013 reported that the brown algae Dichotoma showed higher phenolic content (16.375 $\pm 0.44 \mathrm{mg} \mathrm{GAE} / \mathrm{g})$ than red seaweeds.

Alpha Amylase and Alpha Glucosidase Inhibition Activity of the Stoechospermum Marginatum

Alpha amylase and alpha glucosidase inhibition activity was detected using six and eight hours of ethanol and aqueous extracts of Stoechospermum marginatum and the results are presented in figure 1. Stoechospermum marginatum exhibited $26.7 \pm 1.5$ and $49.5 \pm 0.8$ percent of inhibition activity in six and eight hours of ethanol extracts respectively. Whereas in six and eight hours of aqueous extracts the percentage of inhibition activity of alpha amylase and alpha glucosidase were found to be $64.1 \pm 1.4$ and $73.6 \pm 0.5$ respectively. Alpha glucosidase inhibition activity was found to be $28.9 \pm 0.9$ and $40.3 \pm 1.0$ percent in six hour extraction of ethanol and aqueous respectively. However in eight hours of ethanol and aqueous extracts alpha glucosidase inhibition was $30.9 \pm 0.95$ and $58.1 \pm 0.17$ percent respectively. Unnikrishan et al. (2014) evaluated the brown seaweed Turbinaria oranata against key metabolic enzymes linked to diabetes and reported that the alpha amylase inhibition in methanol extract of $T$. oranata showed maximum inhibition of $96.5 \%$ and the acetone extract showed the maximum (87.6\%) inhibition of alpha glucosidase. Present study reported that the brown seaweed Stoechospermum marginatum had a high percent of alpha amylase and glucosidase inhibition activity. This may be due the valuable amount of phytonutrients and dietary fiber present in seaweed.
Table 1 Nutrient content of the edible seaweed Stoechospermum marginatum

\begin{tabular}{l|c}
\hline \multicolumn{1}{c|}{ Nutrient component } & Amount \\
\hline Carbohydrate $(\mathrm{g})$ & $40.05 \pm 0.8$ \\
Protein $(\mathrm{g})$ & $20.4 \pm 0.75$ \\
Fat $(\mathrm{g})$ & $4.5 \pm 0.4$ \\
Crude fiber (\%) & $14.1 \pm 0.15$ \\
Vitamin C(mg) & $10.6 \pm 4.6$ \\
Beta carotene(mg) & $2.33 \pm 0.4$ \\
Ash (\%) & $13.8 \pm 0.15$ \\
Moisture (\%) & $7.63 \pm 0.25$ \\
\hline
\end{tabular}

Table 2 Phytonutrient composition of the Stoechospermum marginatum

\begin{tabular}{l|c}
\multicolumn{1}{c|}{ Phytonutrient } & Amount/100gm \\
\hline Tannin(mg) & $12.6 \pm 0.41$ \\
Flavonoid(mg) & $6.5 \pm 0.30$ \\
Saponin(mg) & $25.9 \pm 1.8$ \\
Alkaloid(mg) & $7.3 \pm 0.49$ \\
Terpenoids (mg) & $5.4 \pm 0.09$ \\
Steroids (\%) & $47.3 \pm 1.15$ \\
\multicolumn{2}{c}{ Total phenolic content(mg GAE/g ) } \\
Ethanol extract & $141 \pm 1$ \\
Aqueous extract & $86.8 \pm 0.74$ \\
\hline
\end{tabular}

Antioxidant Activity of the Stoechospermum Marginatum

Table 3 illustrates the antioxidant activity of Stoechospermum marginatum evaluated by the DPPH, FRAP assay, Hydrogen peroxide and Beta carotene bleaching assay. DPPH activity of six and eight hours of ethanol extracts of Stoechospermum marginatum showed $36.6 \pm 0.5$ and $39.4 \pm 0.5$ respectively. DPPH activity was detected to be higher in aqueous extracts with $66.2 \pm 1.35$ and $60.3 \pm 0.57$ in eight and six hours respectively than the ethanol extracts. Foon et al. (2013) reported that the methanolic extract of Eucheuma cottanii exhibited $32.74 \pm 0.16,40.54 \pm 0.62$ and $27.86 \pm 0.8$ in DPPH, FRAP and beta carotene scavenging activity respectively. However the DPPH radical activity of the standard BHT was higher $(70.22 \pm 0.40)$ than the seaweed extracts.

Ferric reducing power of Stoechospermum marginatum with six hours of ethanol and aqueous extracts were $1.58 \pm 0.41$ and $0.9 \pm 0.026 \mathrm{mg}$ respectively. Whereas in eight hours of ethanol and aqueous extracts exhibited $1.7 \pm 0.05$ and $1.4 \pm 0.10 \mathrm{mg}$ of ascorbic acid equavalent respectively. The maximum of ferric reducing power was detected in eight hours extract with ethanol and aqueous extract. The standard BHT had $2.43 \pm 0.2 \mathrm{mg}$ of ferric reducing power. Mega and Anjali (2013), reported that the maximum ferric reducing power was detected in ethanolic extract of both brown algae namely Padina tetrastromatica and Dictyota dichotoma (1.168 \pm $0.003 \mathrm{mg} / \mathrm{g}$ and $1.168 \pm 0.0032 \mathrm{mg} / \mathrm{g})$ and methanolic extract of red algae G. corticata $(1.076 \pm 0.001 \mathrm{mg} / \mathrm{g})$. 
Table 3 Antioxidant activity of Stoechospermum marginatum

\begin{tabular}{l|cccc}
\hline \multicolumn{1}{c|}{ Extraction } & DPPH $(\%)$ & FRAP $(\mathrm{mg})$ & H2O2 $(\%)$ & Beta carotene $(\%)$ \\
\hline Six hour ethanol & $36.6 \pm 0.5$ & $1.58 \pm 0.41$ & $44.2 \pm 1.5$ & $63.8 \pm 0.15$ \\
Eight hour ethanol & $39.4 \pm 0.51$ & $1.7 \pm 0.005$ & $37.1 \pm 1.4$ & $65.2 \pm 0.25$ \\
Six hour aqueous & $60.3 \pm 0.57$ & $0.9 \pm 0.026$ & $22.3 \pm 0.7$ & $66.06 \pm 0.39$ \\
Eight hour aqueous & $66.2 \pm 1.35$ & $1.4 \pm 0.10$ & $26.3 \pm 1.1$ & $73.2 \pm 0.25$ \\
BHT & $70.22 \pm 0.4$ & $2.43 \pm 0.20$ & $65.8 \pm 0.81$ & $68.38 \pm 0.72$ \\
\hline
\end{tabular}

Table 4 Physicochemical properties of Stoechospermum marginatum

\begin{tabular}{l|c}
\hline \multicolumn{1}{c|}{ Physicochemical properties } & Stoechospermum marginatum \\
\hline Bulk Density & $0.57 \pm 0.02$ \\
Water Absorption Capacity (g/g DW) & $7.36 \pm 0.39$ \\
Oil Absorption Capacity (g oil/g DW) & $2.36 \pm 0.05$ \\
Swelling Power (ml/g DW) & $16.6 \pm 0.14$ \\
\hline
\end{tabular}

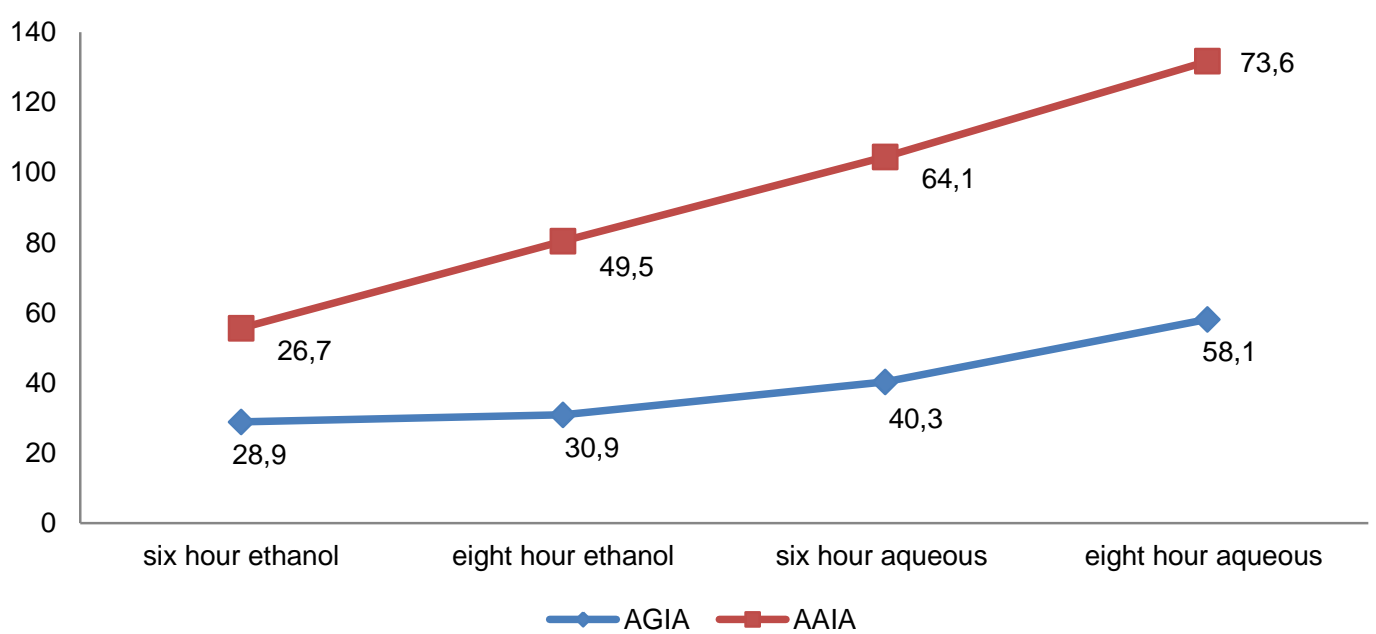

Figure 1 Alpha amylase and alpha glucosidase inhibition activity of Stoechospermum marginatum (AGIA- alpha amylase and alpha glucosidase inhibition activity AAIA- alpha glucosidase inhibition activity)

Maximum inhibition of Hydrogen peroxide was detected in eight hours of ethanol with $44.2 \pm 1.5$ percent, followed by six hours of extraction with ethanol $(37.1 \pm 1.4 \%)$. Whereas in six and eight hours of aqueous extracts of Stoechospermum marginatum was $22.3 \pm 0.7$ and $26.3 \pm 1.1$ percent respectively. Hydrogen peroxide scavenging activity was $65.86 \pm 0.81$ percent for BHT.

The Beta carotene bleaching activity of Stoechospermum marginatum exhibited $63.8 \pm 0.15$ and $65.2 \pm 0.25$ percent in six and eight hours of ethanol extracts and $66.06 \pm 0.39$ and $73.2 \pm 0.25$ percent in six and eight hours of aqueous extracts respectively. Maximum Beta carotene bleaching activity was seen in eight hours of aqueous extract. The standard BHT had $68.38 \pm 0.72$ percent beta carotene bleaching activity. Compared to the standard BHT the brown seaweed Stoechospermum marginatum had a high beta carotene bleaching activity. The DPPH and beta carotene scavenging activities were high in aqueous extracts than in ethanol extracts, similarly the FRAP and hydrogen peroxide scavenging activities were high in ethanol extracts of the seaweed. Walakuck et al. (2011); Kuda and Ikemori, (2009) reported that aqueous extracts of seaweed possessed higher antioxidant activity than ethanol extract. Indu and Seenivasan (2013) reported that maximum antioxidant activity was shown in the brown seaweed of S.wightii by DPPH radical scavenging assay $(79.1 \pm 1.21 \%)$ and the brown seaweed exhibited good antioxidant activity when compared to red and green seaweeds. Antioxidants may have a positive effect on human health since they can protect human body against deterioration by free radicals and Reactive Oxygen Species (ROS), including single oxygen, hydrogen peroxide, superoxide anion and hydroxyl radicals (Ngo et al., 2012). ROS and free radicals attack macro molecules such as DNA, proteins and lipids leading to many health disorders including inflammatory aging, diabetes, neurodegenerative, cardiovascular and cancer disease (Butterfield et al., 2006; Ngo et al., 2011).

Physicochemical Properties Of stoechospermum Marginatum

The physicochemical properties of Stoechospermum marginatum are presented in Table 4. The BD, WAC, $\mathrm{OAC}$, SP of S. marginatum was found to be $0.57 \pm 0.02 \mathrm{~g}$, $7.36 \pm 0.39 \mathrm{~g} / \mathrm{g}$ DW, $2.36 \pm 0.05 \mathrm{~g}$ oil $/ \mathrm{g}$ DW, $16.6 \pm 0.14 \mathrm{ml} / \mathrm{g}$ DW. Benjama and Masniyom (2011), reported that the SWC and WAC of U.pertusa and U.intestinalis ranged from 4.00-6.42 ml/g DW and 7.7-14.96g/g DW respectively, while the WHC of U.intestinalis was higher than U.pertusa. Cox and Abu - Ghannam (2013) stated 
that the seaweeds contain a large amount of dietary fiber and have a high water absorption capacity. The water holding capacity of seaweeds is closely related to the polysaccharide composition (Sanchez Alonso et al., 2006). Stoechospermum marginatum also have good water absorbtion capacity and this indicates the presence of sustantial quantitive of polysaccharides. This may be the reason for the seaweeds to possess a high inhibition activity of carbohydrate hydrolyzing enzymes.

Benjama and Masniyom (2012) determined the OHC of G.tenuistiptta (1.83g oil/g DW) and G.fisheri $(2.35 \mathrm{~g}$ oil/ $\mathrm{g}$ DW) and they stated that $\mathrm{OHC}$ is functional property of food ingredients used for development of food products. Ingredients with high $\mathrm{OHC}$ values allow the stabilization of food emulsions and high fat food products. The $\mathrm{OHC}$ properties of food particles correlated with their surface properties, overall charge density, lipophilic constituents (Fleury and Lahaye, 1991; Elleuch et al., 2011). S. marginatum contain an acceptable WAC and $\mathrm{OAC}$, thus can be used as an ingredient in value added products and may help to improve the texture of food products and enhance the acceptability of the food.

\section{Conclusion}

The brown algae Stoechospermum marginatum was collected from Gulf of Mannar in the pre monsoon season, to evaluate the nutrient, phytonutrient composition, alpha amylase and alpha glucosidase inhibition activity, antioxidant activity and their physicochemical properties. Stoechospermum marginatum had a high amount of carbohydrate, protein, crude fiber and phytonutrients like tannin, steroids, saponin and total phenolic content. Stoechospermum marginatum had high Water absorption and Swelling power. The seaweed possesses a high inhibition activity of alpha amylase and alpha glucosidase and antioxidant activity. Stoechospermum marginatum has a valuable phytonutrient and physicochemical properties this may be a reason for the inhibition of carbohydrate hydrolysing enzymes and radical scavenging activity. The study concludes that the seaweed used as a food ingredient in food products may enhance the nutrient quality and therapeutic value.

\section{References}

Abbas A, Shameel M. 2010. Anatomical studies on Lobophora variegata (Phaeophycota) from the coast of Pakistan. Pakistan Journal of Botany., 42(6): 4169-4176.

Ahmed K, Munawar S, Mahmood T, Mahmood I. 2015. Biochemical analysis of some species of seaweeds from Karachi coastal area. Fuuast journal of Biology., 5(1):43-45.

Alonso SI, Maleki H.AJ, Borderias. 2006. Effect of wheat fibre in frozen stored fish muscular gels. European food research and technology., 223 (4):571-576.

AOAC. 1990. Official Methods of Analysis. $15^{\text {th }}$ ed. Association of Official Analytical Chemists, Washington.

Banerjee K, Ghosh R, Homechaudhuri S, Mitra A. 2009. Seasonal variation in the biochemical composition of red seaweed (Catenella repens) from Gangetic delta, Northeast coast of India. J Earth Syst Sci., 118(5): 497-505.
Benjama O, Masniyom P. 2011. Nutritional composition and physicochemical properties of two green seaweeds (Ulva pertusa and $U$. intestinalis) from the Pattani Bay in Southern Thailand. Songklanakarin J. Sci. Technol., 33 (5): 575-583.

Benjama O, Masniyom P. 2012. Biochemical composition and physicochemical properties of two red seaweeds (Gracilaria fisheri and G. tenuistipitata) from the Pattani Bay in Southern Thailand. Songklanakarin J. Sci. Technol., 34 (2): 223-230.

Benzie IFF, Strain JJ.1999. Ferric reducing (antioxidant) power as ameasure of antioxidant capacity: the FRAP assay. In: Packer L(ed) Oxidants and Antioxidants Volume 299 of Methods in Enzymology. Academic Press, Orlando, 15-27.

Beuchat LR. 1977. Functional and electrophoretic characteristics of succinylated peanut flour protein. J. Agric. Food Chem., 25: 258 -261 .

Bohm BA, Kocipai- Abyazan R.1994. Flavonoid and condensed tannins from the leaves of Vaccinum raticulation and Vaccinum calcyimium. Pacific Sci.,48: 458-463.

Boonchum W, Peerapornpisal Y, Kanjanapothi D, Pekkoh J, Pumas C, Jamjai U, Amornlerdpison D, Noiraksar T, Vacharapiyasophon P. 2011. Antioxidant Activity of some Seaweed from the Gulf of Thailand.International Journal of Agriculture and Biology., 13: 95-99.

Butterfield DA, Ansari R. Sultana. 2006. Journal of Neurochemistry., 98: 1697-1706.

Cox S, Abu-Ghannam N. 2013. Enhancement of the phytochemical and fiber content of beef- patties with Himanthalia elonganta seaweeds. International Journal of Food science and Technology., 48(11): 2239-2249.

Dubois M, Gilles KA, Rebers JK, Smith F.1956. Anal Chem., 26: 350 .

Elleuch M, Bedigian D, Roiseux O, Besbes S, Blecker C, Attia H. 2011. Dietary fiber and fiber-rich byproducts of food processing: Characterization, technological functionality and commercial applications: A review. Food Chemistry., 124: 411421.

El-Said GF, El- Sikaily A. 2013. Chemical composition of some seaweed from Mediterranean Sea coast, Egypt. Environ Monit Assess., 185(7): 6089-6099. DOI: 10.1007/s10661-012-3009-y.

Ferguson N. 1956. A textbook of pharmacognosy, Max Millam Company.

Fleurence J.1999. Seaweed proteins: biochemical nutritional aspects and potential uses. Trends in Food Science and Technology., 10: 25-28.

Fleury N, Lahaye M.1991. Chemical and physico-chemical characterisation of fibres from Lamiaria digitata (Kombu Breton): A physiological approach. Journal of the Science of Food and Agriculture., 55: 389-400.

Foon TS, Lian Ai, Kuppusamy P, Mashitah M, Yusoff, Govindan N. 2013. Studies on in-vitro antioxidant activity of marine edible seaweeds from the east coastal region of Peninsular Malaysia using different extractionmethods. Journal of Coastal Life Medicine., 1(3): 193-198.

Harborne JB.1973. Phytochemical methods. A guide to modern techniques of plan analysis. Chapman A and Hall. London.

Harris LJ, Ray SN. 1935. Ascorbic acid, Lancet, 1.

Indrawati R, Sukowijoyo H, Indrriatmoko, Wijayanti DE, Limantara L. 2015. Encapsulation of brown seaweed pigment by freeze drying characterization and its stability during storage. Procedia chemistry., 14:353-360.

Indu H, Seenivasan R. 2013. In Vitro Antioxidant Activity of Selected Seaweeds From Southeast Coast Of India. International Journal of Pharmacy and Pharmaceutical Science., 5(2): 474-484.

Jagadeesan L, Kannadasan A, Anantharaman P, Perumal P, Thangaraj M. 2010. Assessment of Ammonium uptake by marine macroalga Gracilaria verrucosa (Rhodophyta). Current Research Journal of Biological Sciences., 2(2):150-153.

Kaimoussi A, Mouzdahir A, Saih A.2004. Variations saisonnières des teneurs enlittoral de la ville d'El Jadida (Maroc). Comptes Rendus Biologies., 327: 361-369. 
Krishnan MR, Kumar N. 2010. Scio economic dimensions of seaweeds farming in india. CMFRI Special publication no, 104 Published by G.Syda Rao. Central marine fisheries research institute, Kochi.

Krisnaveni S, Theymoli B, Sadasivam S. 1984. Food chemistry.,15.

Kuda T, Ikemori T.2009. Minerals, polysaccharides and antioxidant properties of aqueous solutions obtained from macroalgal beachcasts in the Noto Peninsula, Ishikawa. Japanese Food Chemistry., 112: 575-581.

Kumbhar D, Rohini P, Surekha B, Sabale RA. 2014. Phytochemical screening of seaweeds from sindhudurg District of Maharashtra. International Journal of Pharmaceutical Sciences Review and Research.,29(1): 77-81.

Leach HW, McCowen LD, Schoch TJ.1959. Structure of the starch granules. In: Swelling and solubility patterns of various starches. Cereal Chem.,36:534 - 544.

Lowry OH, Rosebrough NJ, Farr AL, Randall RJ. 1951. Protein measurement with Folin phenol reagent. J. Biol.Chemisty.,193:265-275.

Malik E.P, Singh M.B. 1980. Plant Enzymology and Hittoenzymology. 1st Ed., New Delhi: Kalyani Publishers.

Mann A, Barnabas BB, Daniel II. 2010. The effects of mathonolic extracts of Anogeissusleicarpus and Terminalia avicenniodes on the growth some food born microorganisms. Autr. Journal of Basic Applied Science., 4(2): 6041-6045.

Maynard A J.1970. Methods in Food analysis, Academic Press, New York.

Megha MN, Anjali SB. 2013. Antioxidant Potential of Seaweeds from Kunakeshwar along the West Coast Maharashtra. Asian Journal of Biomedical and Pharmaceutical Sciences., 3(22): 4550.

Mesyaz B, Rybak A. 2010. A biotic factor affecting the development of ulva sp (ulvaphyceae, chlorophyta) in fresh water ecosystems. Aquat ecol., 45: 75-87.

Miller GL.1959. Use of Dinitro salicylic acid reagent for determination of reducing sugar. Analytical Chemistry., 31:426428.

Mohamed S, Hashin S.N, Rahman H.A. 2012. Seaweeds a sustainable functional foods for complementary and alternative therapy. Trends Food Sci., Tech., 23: 83-96.

Moon, Kim. 1999. Iodine content of human milk and dietary iodine intake of Korean lactating mothers. International Journal of Food Science and Nutrition., 50(3): 165-171.

Murugaiyan K, Narasimman S, Anatharaman P. 2012. Proximate composition of marine macro algae from Seeniappa Dharka, Gulf of Mannar region, Tamil Nadu. International Journal of Research in Marine Sciences., 1(1): 1-3.

Narayana K, Rao N.MS.1984. Effect of partial proteolysis on the functional properties of winged pea (Psophocarpus tetragonolobus) flour. J. Food Sci., 49: 944- 947.

Ngo DH, VO TS, Ngo DN, Wijesekara I, Kim SK. 2012. Biological activities and potential health benefits of bioactive peptides derived from marine organisms. International Journal of Biological Macromolecules., 51: 378-383.
Ngo DH, Wijesekara I, VO TS, Ta QV, Kim SK. 2011. Food Research International., 44: 523-529.

Obdoni BO, Ochuko PO.2001. Phytochemical studies and comparative efficacy of the crude extracts of some Homostatic plants in Edo and Delta States of Nigeria. Glob J Pure Appl Sci., 8b: 203-208.

Ortiz J, Romero N, Robert P, Araya J, Lopez-Hernández J, Bozzo CE, Navarrete CE, Osorio A, Rios J. 2006. Dietary fiber, amino acid, fatty acid and tocopherol content of the edible macroalgaes Ulva lactuca and Durvillaea antaactica. Food chemistry., 99: 98-104.

Parthiban C, Saranya C, Girija K, Hemalatha A, Suresh M, Anantharaman P. 2013. Evaluation of in vitro antioxidant properties of some selectedseaweeds from Tuticorin coast.International Journal of Current Microbiology and Applied Science., 2(9): 64-73.

Paul JB. 2013. Seasonal variability of Laurencia species (red seaweed) in Tirunelveli region, the South East Coast of Tamil Nadu, India. Research Journal of Marine Sciences., 1(1): 6-9.

Peng Y, Xie E, Zheng K, Fredimoses M, Yang X, Zhou X, Wang Y, Yang B, Lin X, Liu F, Liu Y. 2013. Nutritional and Chemical Composition and Antiviral Activity of Cultivated Seaweed Sargassum naozhouense Tseng et Lu. Mar Drugs.,11: 20-32.

Rajamani K, Somasundaram ST, Manivasagam T, Balasubramanian V, Anantharaman P. 2010. Hepatoprotective activity of brown alga padina boergesenii against ccl4 induced oxidative damage in wistar rats. As pac J trp med., 696-701.

Ranganna S.1976. In: Manual of Analysis of Fruits and Vegetables Products. McGraw Hill., New Delhi.

Roslin S. 2003. Seasonal variations in the protein content of marine algae in relation to environmental parameters in Arockiapuram coast. Seaweed Research Utilization., 25: 77-86.

Ruch RJ, Cheng SJ, Klaunig JE. 1989. Prevention of cytotoxicity and inhibition of intercellular communication by antioxidant catechins isolated from Chinese green tea. Carcinogenesis., 10: 1003-1008.

Schanderl SH. 1970. In Method in Food Analysis. Academic press. New York.

Seafood plus, 2008. www.seafeedplus.org/fileadmin/files/ news/2004-01-22SFRDIlaunch Brussels. Pdf (Accessed 08 May 2010)

Unnikrishan PS, Suthindhiran MA, Jayasri. 2014. Inhibitory potential of Turbinaria ornate against key metabolic enzymes linked to diabetes. BioMed Research International., http://dx.doi.org/10.1155/2014/783895.

Velioglu YS, Mazza G, Gao L, Oomah BD. 1998. Antioxidant activity and total phenolics in selected fruits, vegetables, and grain products. J Agric Food Chem., 46(10): 4113-4117.

Wang M, Li J, Rangarajan M, Shao Y, LaVoie, EJ, Huang T, Ho C. 1998. Antioxidative phenolic compounds from sage (salvia officinalis). J Agric Food Chem., 46: 4869-487. 